\title{
In vitro association of six oviductal fluid proteins with the bovine zona pellucida
}

\author{
A. L. Staros and G. J. Killian* \\ Dairy Breeding Research Center, Department of Dairy and Animal Science, \\ The Pennsylvania State University, University Park, PA 16802, USA
}

\begin{abstract}
Oviductal fluid proteins have been shown to associate with gametes in several species. The objective of the present study was to identify bovine oviductal fluid proteins that associate with the bovine zona pellucida. Oviductal fluid was obtained daily from two dairy cows with normal oestrous cycles via indwelling oviductal cannulae. Fluid was collected from the ampullary and isthmic regions of the same oviduct. Oviductal fluid samples were pooled by oviduct region and according to stage of the oestrous cycle as determined by the concentration of serum progesterone. Samples collected when serum progesterone concentrations were $>1.5 \mathrm{ng} \mathrm{ml}^{-1}$ were combined into luteal pools. Non-luteal pools consisted of oviductal fluid samples collected on days when serum progesterone concentrations were $\leq 1.5 \mathrm{ng} \mathrm{ml}{ }^{-1}$. Each oviductal fluid sample was assayed for protein concentration, and an aliquot equivalent to $10 \mathrm{mg} \mathrm{ml} \mathrm{m}^{-1}$ was biotinylated using biotinamidocaproate $N$-hydroxysuccinimide ester at a concentration of $1 \mathrm{mg} \mathrm{ml}{ }^{-1}$. Cumulus-free, non-viable bovine oocytes were incubated in the biotinylated oviductal fluid samples for $3.5 \mathrm{~h}$. Oocytes were washed, the zonae mechanically ruptured, solubilized, and subjected to onedimensional SDS-PAGE. Separated proteins were transferred to nitrocellulose and probed with avidin-horseradish peroxidase. Five biotinylated oviductal fluid proteins were found to associate with the zona pellucida in all treatments. These proteins had apparent molecular masses of $80,74,60,45$, and $30 \mathrm{kDa}$. An additional protein, of molecular mass $95 \mathrm{kDa}$, was found associated with zonae from oocytes incubated in non-luteal fluid of both regions, but not from oocytes incubated in luteal fluid. This protein was shown to be bovine oestrus-associated protein by using a monospecific polyclonal antibody.
\end{abstract}

\section{Introduction}

Mammalian fertilization occurs within a complex microenvironment provided by the oviduct of the female genital tract. The oviduct, and the fluid contained within, provide an environment to ensure successful transport and survival of gametes, and early embryonic development.

Oviductal fluid is composed of a selective serum transudate (Feigelson and Kay, 1972) and secretory products from the oviductal epithelium (Oliphant and Ross, 1982; Sutton et al., 1984). Oviduct-specific secretions have been a major research focus in recent years, leading to the identification of oviductspecific proteins that appear at, or near, oestrus or ovulation. These oestrus- and ovulation-associated proteins have been identified in numerous species including mice (Kapur and Johnson, 1985), hamsters (Léveillé et al., 1987), sheep (Sutton et al., 1984), baboons (Fazleabas and Verhage, 1986), humans (Lippes et al., 1981), and cows (Gerena and Killian, 1990). Although the precise function of most of these proteins has not been determined, in several species they have been shown to

${ }^{*}$ Correspondence.

Received 19 May 1997. associate with spermatozoa (Sutton et al, 1984; Lippes and Wagh, 1989; McNutt et al., 1992), ovulated eggs (Kapur and Johnson, 1985; Boice et al., 1990; Wegner and Killian, 1991; Buhi et al., 1993), and embryos (Kapur and Johnson, 1986; Gandolfi et al., 1989; Wegner and Killian, 1991; Boice et al., 1992). Many of these studies have demonstrated that oviductal fluid proteins associate with the zona pellucida both in vivo and in vitro, suggesting a possible role in fertilization or embryonic development.

Zona pellucida proteins have been implicated in speciesspecific sperm binding, the prevention of polyspermy, and embryo protection between fertilization and implantation (Dunbar et al., 1991). The function of oviduct-specific proteins that associate with gametes and embryos is generally unknown, but it is likely that these proteins play an important role in the reproductive process. For this study, only naturally cyclic cows were used since exogenous hormones appear to alter oviductal secretion and physiology. Evidence that embryos resulting from hormone-treated animals do not possess the same capacity for in vitro development as non-treated animals suggests that exogenous hormones may have a deleterious effect on oviductal function (Pinkert et al., 1989). The purpose of this study was to identify proteins in oviductal fluid 
that associate with the zona pellucida of bovine oocytes, and to determine any differences in the pattern of association between regions of the oviduct or stages of the oestrous cycle.

\section{Materials and Methods}

\section{Collection and preparation of oviductal fluid}

Oviductal fluid was recovered every $24 \mathrm{~h}$ from indwelling ampullary and isthmic cannulae from each of two Holstein cows (Bos taurus) as described by Kavanaugh et al. (1992). The stage of the oestrous cycle was determined by a progesterone radioimmunoassay using blood serum samples taken each day at the time of collection of oviductal fluid (Killian et al., 1989). Serum progesterone concentrations $>1.5 \mathrm{ng} \mathrm{ml}^{-1}$ were considered to be luteal, whereas samples with serum progesterone $\leq 1.5 \mathrm{ng} \mathrm{ml}^{-1}$ were considered to be non-luteal (Killian et al., 1989). Visible signs of oestrus were also noted.

Oviductal fluid samples taken daily were assayed for total protein (Bradford, 1976) and evaluated for protein composition using one-dimensional SDS-PAGE (Laemmli, 1970) to ensure each sample had a protein profile typical of other cattle studied in our laboratory. These samples were stored in liquid nitrogen until pooled across cycle stage for each cow.

Protein concentration of fluid from each region of the oviduct at each stage of the oestrous cycle was determined before the protein biotinylation procedure. Typically $2.5 \mathrm{mg}$ of oviductal fluid protein was diluted up to $250 \mu \mathrm{l}$ with sodium bicarbonate buffer $\left(0.25 \mathrm{~mol} \mathrm{NaHCO}_{3} \mathrm{l}^{-1}, \mathrm{pH}\right.$ 8.5). The biotinylation reagent, biotinamidocaproate $\mathrm{N}$-hydroxysuccinimide ester (Sigma, St Louis, MO) was dissolved in $N, N$ dimethylformamide at a concentration of $4 \mathrm{mg} \mathrm{ml}^{-1}$ before being added to the protein. Immediately after preparation, $1 \mathrm{mg} \mathrm{ml}^{-1}$ of biotin solution was added to each oviductal fluid sample. Oviductal fluid samples were incubated with the biotin solution for $2 \mathrm{~h}$ at $4^{\circ} \mathrm{C}$ with occasional mixing. The reaction was stopped by the addition of $2.5 \mathrm{mg}$ glycine. Excess biotin was removed by dialysis against two changes of PBS ( $\mathrm{pH} 7.2)$ using $10 \mathrm{kDa}$ molecular mass cut-off dialysis tubing (Spectrum, Houston, TX).

\section{Collection and incubation of bovine oocytes}

Bovine ovaries obtained from an abattoir were transported to the laboratory on ice in Dulbecco's PBS ( $\mathrm{pH} 7.4$ ) without $\mathrm{CaCl}_{2}$ (Sigma). Ovaries were washed in $0.9 \%$ saline containing $1 \mathrm{mmol}$ Hepes $\mathrm{l}^{-1}$ (Sigma) and stored at $-20^{\circ} \mathrm{C}$ until used. Ovaries were thawed in a water bath kept at $4^{\circ} \mathrm{C}$ for $3-4 \mathrm{~h}$. Oocytes were obtained from thawed ovaries by aspiration of $1-5 \mathrm{~mm}$ follicles using an 18 gauge needle and $10 \mathrm{ml}$ syringe. Aspirates were placed into $15 \mathrm{ml}$ conical tubes containing 2-3 ml of a low bicarbonate-Hepes medium (Bavister et al., 1983) to allow oocytes and cellular debris to settle to the bottom. Oocytes were retrieved from the soft pellets and washed three times in fresh Hepes medium to remove follicular fluid and cellular debris. Oocytes were stored at $-80^{\circ} \mathrm{C}$ until used. An aliquot of biotinylated oviductal fluid with a protein concentration of approximately $7 \mathrm{mg} \mathrm{ml}^{-1}$ was pipetted onto the bottom of a $35 \mathrm{~mm} \times 15 \mathrm{~mm}$ Petri dish and covered with
2-3 ml of mineral oil. Previously frozen intact oocytes were gently vortexed for $20 \mathrm{~s}$ to remove any cumulus cells that were not dislodged during the freeze-thaw process. Oocytes with visible cumulus material remaining were not used in the study. Oocytes were washed three times in fresh sodium bicarbonate buffer. One hundred cumulus-free oocytes were placed in each sample of biotinylated oviductal fluid (ampullary luteal; isthmic luteal; ampullary non-luteal; isthmic non-luteal), $7 \mathrm{mg} \mathrm{ml}^{-1}$ non-biotinylated oviductal fluid (ampullary luteal; isthmic luteal; ampullary non-luteal; isthmic non-luteal), biotin solution alone $\left(75 \mu \mathrm{l}\right.$ of $4 \mathrm{mg} \mathrm{ml}^{-1}$ solution in $250 \mu \mathrm{l}$ sodium bicarbonate buffer), or bicarbonate buffer alone. All treatments were incubated at $4^{\circ} \mathrm{C}$ for $3.5 \mathrm{~h}$ with slow, constant shaking to prevent oocytes from adhering to the bottom of the Petri dish.

\section{Isolation and solubilization of zonae pellucidae}

After incubation, oocytes were retrieved and washed three times in fresh sodium bicarbonate buffer $(0.25 \mathrm{~mol} \mathrm{NaHCO}$ $1^{-1}, \mathrm{pH} 8.5$ ). Zonae were removed by slowly drawing the oocyte into a 33 gauge needle resulting in the physical disruption of the oocyte and expulsion of oocyte contents through a break in the zona pellucida. A 31 gauge needle was used to wash isolated zonae twice in fresh sodium bicarbonate buffer to remove any oocyte debris. Zonae were counted and placed in $1.5 \mathrm{ml}$ microcentrifuge tubes. Approximately 85-90 zonae of the original 100 were recovered by this method for each treatment. Zonae were solubilized by addition of $15 \mu \mathrm{l}$ SDS sample treatment buffer $(2 \% \mathrm{w} / \mathrm{v})$ used to prepare samples for electrophoresis.

\section{One-dimensional gel electrophoresis and protein detection}

SDS polyacrylamide gels $(190 \mathrm{~mm} \times 150 \mathrm{~mm} \times 1.5 \mathrm{~mm}$ ) were cast with a $10.0-17.5 \%$ acrylamide linear gradient separating gel and a $4 \%$ acrylamide stacking gel. Aliquots equivalent to $30 \mu \mathrm{g}$ protein were prepared for regional, oestrous cycle-staged, biotinylated oviductal fluid and unlabelled oviductal fluid. Samples containing biotinylated oviductal fluid proteins associated with the zonae were prepared as described above. All samples were placed in a boiling water bath for 5 min to denature the protein before application to individual wells within the stacking gel. Additionally, biotinylated (Bio-Rad, Hercules, CA) or pre-stained molecular mass markers (Bio-Rad) were loaded onto each gel. Protein blotting and detection were performed according the method of Towbin et al. (1979). Immediately after electrophoresis, proteins were transferred from gels to nitrocellulose paper $(0.45 \mu \mathrm{m}$ pore size) using a MilliBlot semi-dry transfer system (Millipore, Bedford, MA).

Blots of biotinylated oviductal fluid proteins, biotinylated zonae and zonae incubated in biotinylated oviductal fluid were probed with a conjugate of avidin and horseradish peroxidase (Bio-Rad). Non-specific binding sites were blocked by incubating the blot in PBS (pH 7.2) containing 0.5\% (v/v) polyoxyethylenesorbitan monolaurate (PBS-Tween), $5 \%$ heat-inactivated normal goat serum and $3 \% \mathrm{H}_{2} \mathrm{O}_{2}$ overnight at $4^{\circ} \mathrm{C}$. After blocking, blots were incubated in the avidin-horseradish peroxidase conjugate diluted 1:1000 in PBS-Tween containing 


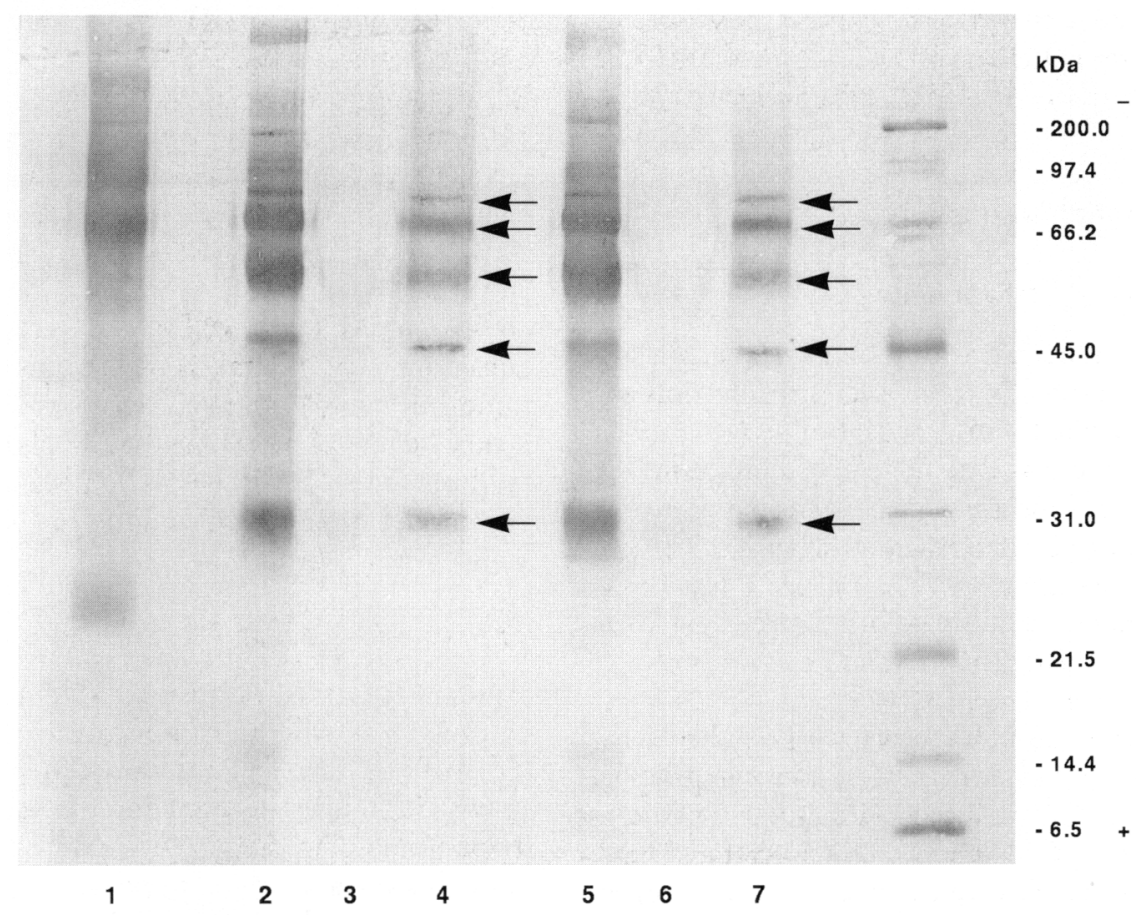

Fig. 1. Protein blot of biotinylated luteal oviductal fluid proteins and zonae pellucidae from bovine oocytes incubated with biotinylated bovine luteal oviductal fluid. Lane 1: zonae from oocytes incubated in biotin solution alone (100 zonae). Lanes 2 and 5: biotinylated isthmic and ampullary luteal oviductal fluid, respectively ( $30 \mu \mathrm{g}$ protein). Lanes 3 and 6: non-biotinylated isthmic and ampullary luteal oviductal fluid, respectively ( $30 \mu \mathrm{g}$ protein). Lanes 4 and 7: zonae from oocytes incubated in biotinylated isthmic and ampullary luteal oviductal fluid, respectively (100 zonae). Arrows indicate biotinylated luteal oviductal fluid proteins associated with zonae pellucidae.

$1 \%(\mathrm{v} / \mathrm{v})$ normal goat serum to maintain blocking for $2 \mathrm{~h}$ at room temperature. Blots were washed twice in PBS-Tween containing $1 \%$ normal goat serum and subsequently incubated in 3,3'-diaminobenzidine solution until the desired signal intensity was achieved. Blots were washed in distilled $\mathrm{H}_{2} \mathrm{O}$ and placed on clean filter paper to dry.

Some blots were also probed with either a monospecific polyclonal antibody prepared against the bovine oestrusassociated protein (King and Killian, 1994), or a commercial antibody against BSA (Sigma) to characterize further the biotinylated oviductal fluid proteins associating with the zona pellucida. To ensure that all oviductal fluid proteins were biotinylated using the procedure described, labelled and unlabelled samples of non-luteal oviductal fluid proteins were subjected to electrophoresis and transferred to nitrocellulose as described. These blots were probed with a polyclonal antibody prepared against whole oviductal fluid. After blocking, as described above, blots were incubated in primary antibody diluted 1:1000 for the oestrus-associated protein, or 1:20000 for the serum albumin in PBS-Tween containing 1\% normal goat serum. Excess antibody was eliminated by two washes in PBS-Tween and 1\% normal goat serum before incubation in the secondary antibody (anti-rabbit IgG-peroxidase conjugate, Sigma) diluted 1:1000. Blots were washed twice before chromogenic development.

After development, blots were scanned on a Bio-Rad Model GS-670 Imaging Densitometer. Molecular mass determinations were made for the individual protein bands using the Molecular Analyst software (Bio-Rad).

\section{Results}

Blots of biotinylated ampuliary luteal and isthmic luteal proteins associated with the zona pellucida are shown (Fig. 1). Five distinct proteins of approximately $80,74,60,45$, and $30 \mathrm{kDa}$, as determined by data obtained from the Imaging Densitometer (Bio-Rad), were observed to associate with the zona pellucida. No regional differences in the pattern of protein association were found between the luteal stage biotinylated oviductal fluid samples. A representative blot of biotinylated isthmic non-luteal oviductal fluid and biotinylated ampullary non-luteal oviductal fluid shows five proteins associated with the zona pellucida of similar molecular masses as mentioned above, as well as a $95 \mathrm{kDa}$ protein (Fig. 2). Again, no regional differences in protein pattern were observed between nonluteal stage samples. The $95 \mathrm{kDa}$ protein associated with the zonae exposed to biotinylated non-luteal fluid, but not biotinylated luteal fluid, indicates a difference between luteal and non-luteal oviductal fluid due to the stage of the oestrous cycle.

In all cases, these proteins were also found in the respective samples of control biotinylated oviductal fluid, but not in the control biotinylated zonae sample. This control result indicates that the association of these proteins with the zona pellucida 


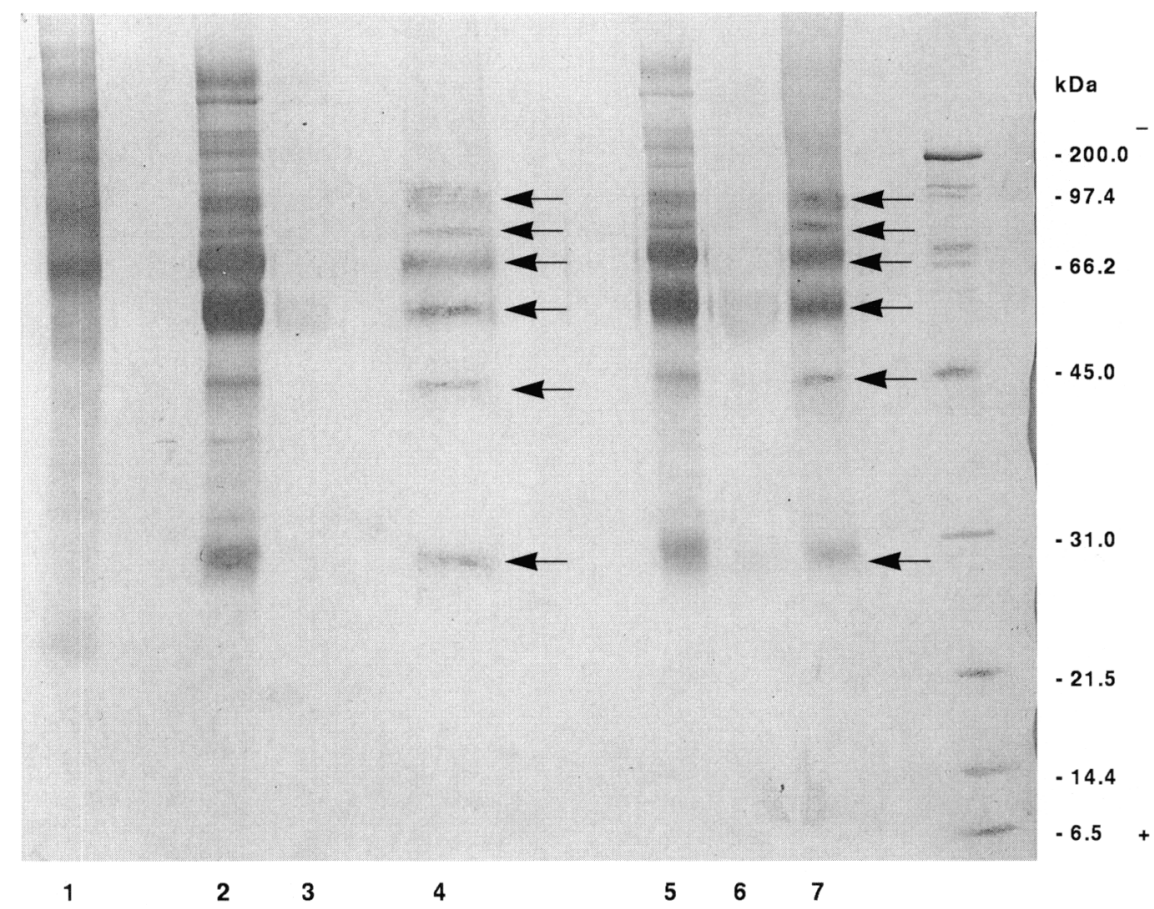

Fig. 2. Protein blot of biotinylated non-luteal oviductal fluid proteins and zonae pellucidae from bovine oocytes incubated with biotinylated bovine non-luteal oviductal fluid. Lane 1: zonae from oocytes incubated in biotin solution alone ( 100 zonae). Lanes 2 and 5: biotinylated isthmic and ampullary non-luteal oviductal fluid, respectively ( $30 \mu \mathrm{g}$ protein). Lanes 3 and 6 : non-biotinylated isthmic and ampullary non-luteal oviductal fluid, respectively ( $30 \mu \mathrm{g}$ protein). Lanes 4 and 7: zonae from oocytes incubated in biotinylated isthmic and ampullary non-luteal oviductal fluid, respectively (100 zonae). Arrows indicate biotinylated non-luteal oviductal fluid proteins associated with zonae pellucidae.

results from their presence in oviductal fluid, not from non-specific binding of the avidin-peroxidase conjugate to the nitrocellulose. No protein was detected in the control nonbiotinylated sample lanes, indicating adequate blocking of non-specific binding sites. In all cases, no protein bands were visible in the lanes containing zonae from oocytes incubated in non-biotinylated oviductal fluid (data not shown).

Blots incubated with an antibody against bovine oestrusassociated protein (Fig. 3) confirmed that the $95 \mathrm{kDa}$ protein from the biotinylated ampullary non-luteal and isthmic nonluteal samples that associated with the zonae was in fact the previously defined bovine oestrus-associated protein (King and Killian, 1994). Blots incubated with the anti-BSA (Fig. 4) detected albumin, with an approximate molecular mass of $74 \mathrm{kDa}$, associating with the zona pellucida. The blots incubated with the polyclonal antibody against whole oviductal fluid showed that the pattern of biotinylated oviductal fluid proteins reflects the protein composition of unlabelled oviductal fluid (data not shown).

\section{Discussion}

Bovine oviductal fluid comprises a serum transudate and secretory products from the oviductal epithelium (Ellington, 1991). Gerena and Killian (1990) showed that the total protein present in oviductal fluid was higher during the non-luteal than the luteal phase, and that the protein concentration in oviductal fluid was approximately $20-30 \%$ of that found in blood serum. Albumin is the major protein in oviductal fluid accounting for $29-35 \%$ of total protein, while the oestrus-associated protein accounts for up to $7.3 \%$ of the total oviductal fluid protein during the non-luteal phase (Gerena and Killian, 1990). Proteins from bovine oviductal fluid have been shown to associate with spermatozoa (McNutt et al., 1992; King and Killian, 1994), eggs, and embryos (Wegner and Killian, 1991; Boice et al., 1992). The specific role of oviductal fluid proteins associating with gametes and embryos is unknown, but is suspected to be one of functional importance.

The present study found that several oviductal fluid proteins associate with the zona pellucida and that the pattern of association differed with the stage of the oestrous cycle, but not between the regions of the oviduct. A high molecular mass protein $(95 \mathrm{kDa})$ associated with the zona pellucida from both biotinylated isthmic non-luteal and ampullary non-luteal fluid, but not from luteal fluid. This $95 \mathrm{kDa}$ protein was shown to be bovine oestrus-associated protein by using a monospecific polyclonal antibody. Wegner and Killian (1991) made similar observations using a fluorescent-labelled antibody to this protein. The oestrus-associated protein bound to the zonae of eggs and embryos fluoresced more strongly when incubated with non-luteal fluid than with luteal fluid. The oestrusassociated protein is observed in both luteal and non-luteal oviductal fluid, but the amount detected is significantly greater 


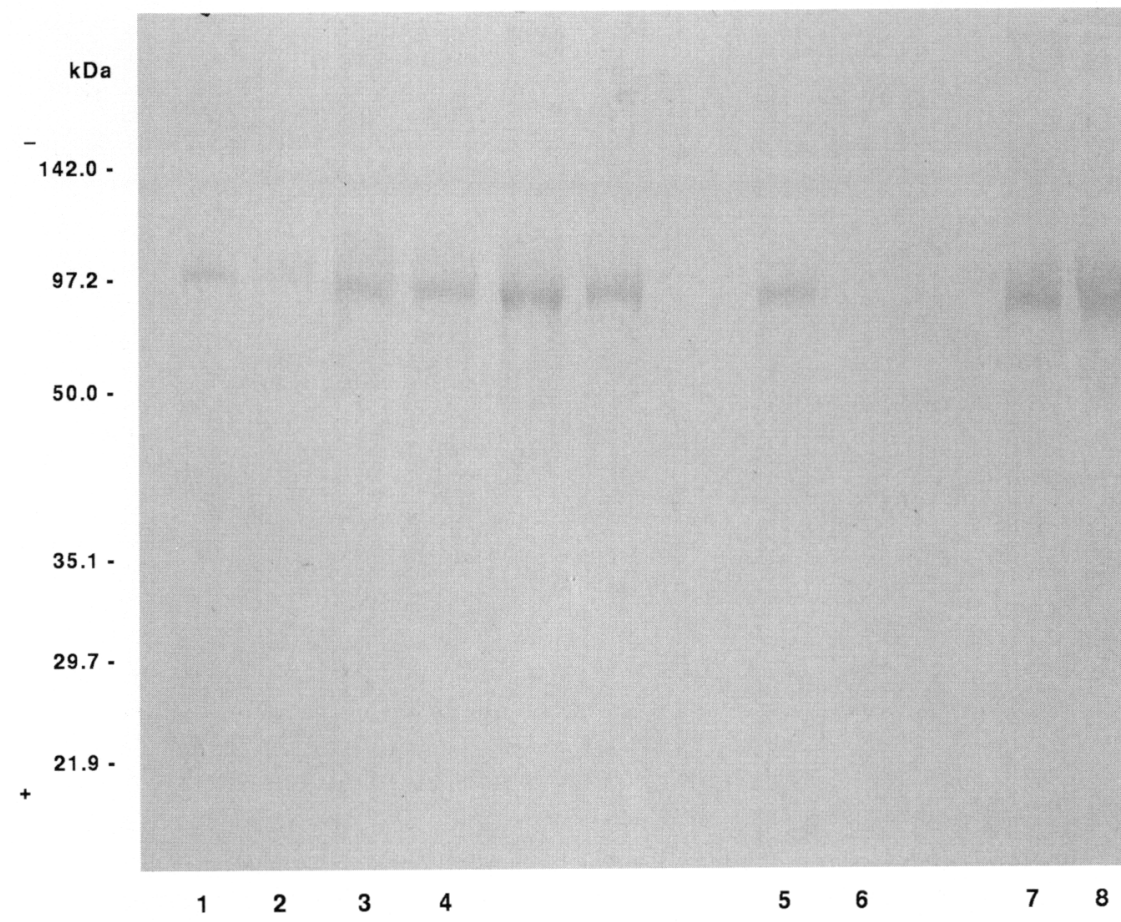

Fig. 3. Western blot of biotinylated oviductal fluid proteins and zonae pellucidae from bovine oocytes incubated with biotinylated bovine oviductal fluid and probed with a polyclonal antibody prepared against bovine oestrus-associated protein. Lanes 1 and 3: biotinylated luteal and non-luteal ampullary oviductal fluid, respectively ( $50 \mu \mathrm{g}$ protein). Lanes 2 and 4 : zonae from oocytes incubated in biotinylated luteal and non-luteal ampullary oviductal fluid, respectively (100 zonae). Lanes 5 and 7: biotinylated luteal and non-luteal isthmic oviductal fluid, respectively $(50 \mu \mathrm{g}$ protein). Lanes 6 and 8: zonae from oocytes incubated in biotinylated luteal and non-luteal isthmic oviductal fluid, respectively (100 zonae).

during the non-luteal phase, and is at a maximum on day 2 of the cycle (Gerena and Killian, 1990). This present study is the first to demonstrate that several other proteins originating in oviductal fluid associate with the zona pellucida. It appears that uptake of these proteins does not require mature egg cytoplasm since immature, non-viable oocytes were used in the present study. This notion supports previous findings that the uptake of bovine oestrus-associated protein does not require egg maturation (Wegner and Killian, 1991). However, the association of the oestrus-associated protein with the zona pellucida of non-viable oocytes is not artifactual, since it has also been detected on the zonae of embryos flushed from the uterus (Wegner and Killian, 1991). Also, preliminary data using oocytes matured in vitro, as described by McNutt and Killian (1991), show a similar pattern of oviductal fluid proteins associating with the zona pellucida as was found in the current study (data not shown).

The detection of an albumin of molecular mass $74 \mathrm{kDa}$ associating with the zona pellucida, in addition to the detection of other albumins of a wide molecular mass range of $62-74 \mathrm{kDa}$ in lanes containing oviductal fluid alone, suggests that the zona pellucida has a preferential affinity for higher molecular mass forms of albumin. Alternatively, this observation may be due to an alteration in the migration pattern of albumin due to residual binding of zona pellucida proteins Additional studies will need to be conducted to determine whether the bovine zona pellucida has a specific affinity for albumin of high molecular mass.
Oviductal fluid proteins have been found to associate with the zona pellucida in many species including hamsters (Fox and Shivers, 1975), pigs (Brown and Cheng, 1986), sheep (Gandolfi et al., 1989), baboons (Boice et al., 1990), and cows (Wegner and Killian, 1991), but no functional correlate for this phenomenon has been demonstrated. Several studies have shown that in vitro fertilization and embryonic development can be improved when eggs and embryos are exposed to oviductal fluid or oviductal cells (Bavister, 1988; Gandolfi et al., 1989). In hamsters, binding of spermatozoa to ova is decreased and in vitro fertilization inhibited if the ova are treated with a monoclonal antibody prepared against an oviductal glycoprotein (Sakai et al., 1988), suggesting that oviductal fluid proteins added to the zona pellucida may mediate sperm-egg binding. Enhanced embryonic development has been noted when embryos are co-cultured with intact oviducts (Minami et al., 1988), oviductal epithelium (Gandolfi and Moor, 1987) and oviduct-conditioned medium (Eyestone and First, 1989). However, successful in vitro fertilization and embryonic development can be achieved in the absence of these components, suggesting that oviductal fluid and oviductal cells play a facilitatory role in fertilization and development.

Oviductal fluid has recently been implicated in affecting movement characteristics during capacitation of bovine spermatozoa (McNutt et al., 1994; Grippo et al., 1995) and in enhancing sperm binding and penetration of bovine oocytes (Way et al., 1997), although these studies have not shown oviductal fluid proteins to be directly involved in these 


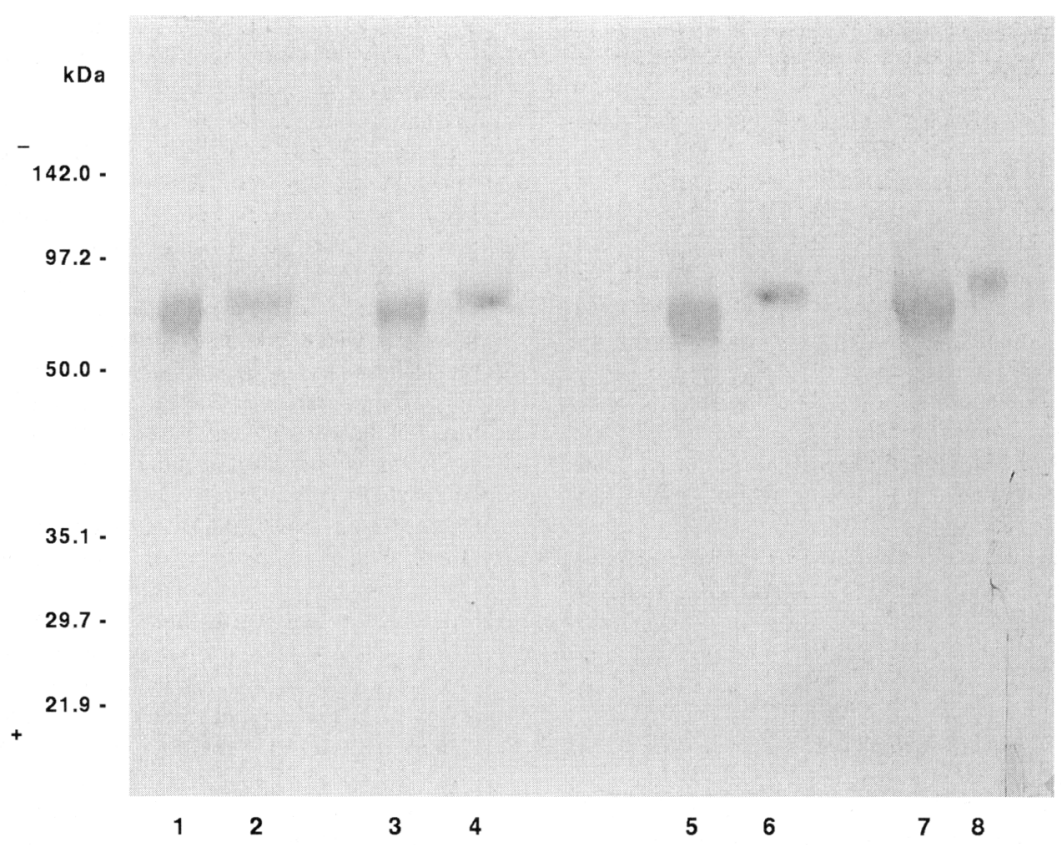

Fig. 4. Western blot of biotinylated oviductal fluid proteins and zonae pellucidae from bovine oocytes incubated with biotinylated bovine oviductal fluid and probed with anti-bovine serum albumin. Lanes 1 and 3: biotinylated luteal and non-luteal ampullary oviductal fluid, respectively $(50 \mu \mathrm{g}$ protein). Lanes 2 and 4: zonae from oocytes incubated in biotinylated luteal and non-luteal ampullary oviductal fluid, respectively (100 zonae). Lanes 5 and 7: biotinylated luteal and non-luteal isthmic oviductal fluid, respectively $(50 \mu \mathrm{g}$ protein). Lanes 6 and 8: zonae from oocytes incubated in biotinylated luteal and non-luteal isthmic oviductal fluid, respectively (100 zonae).

phenomena. Substantial data indicate that oestrus-associated proteins are present in the oviduct of many species, but few studies have attempted to attribute a function to these proteins. Hill et al. (1992) found that ovine blastocysts cultured in the presence of an oestrus-associated protein-containing fraction of oviductal fluid had significantly more nuclei than those cultured in control medium. King et al. (1994) showed that the bovine oestrus-associated protein has the ability to capacitate spermatozoa and promote the ability of spermatozoa to fertilize in vitro. Abe et al. (1995) demonstrated that medium containing the bovine oestrus-associated protein was able to maintain the viability and motility of bovine spermatozoa more effectively over a $12 \mathrm{~h}$ incubation period, than was medium alone. Studies conducted with the bovine oestrus-associated protein clearly indicate the potential importance of this protein in the development of gametes and embryos. However, further studies are needed to determine the precise role of this, and other, oviductal fluid proteins associated with gametes in sperm-egg interaction, preparation of the oocyte for fertilization and early embryonic development.

The assistance of the staff at the Dairy Breeding Research Center is greatly appreciated. This research was supported in part by USDA grants 91-37203-6554 and 96-35203-3428.

\section{References}

Abe H, Sendai Y, Satoh T and Hoshi H (1995) Bovine oviduct-specific glycoprotein: a potent factor for maintenance of viability and motility of bovine spermatozoa in vitro. Molecular Reproduction and Development 42 226-232
Bavister BD (1988) Role of oviductal secretions in embryonic growth in vivo and in vitro. Theriogenology 29 143-154

Bavister BD, Leibfried ML and Lieberman G (1983) Development of preimplantation embryos of the golden hamster in a defined culture medium Biology of Reproduction 28 235-247

Boice ML, Mavrogianis PA, Murphy CN, Prather RS and Day BN (1992) Immunocytochemical analysis of the association of bovine oviduct-specific glycoproteins with early embryos Journal of Experimental Zoology 263 225-229

Boice ML, McCarthy TJ, Mavrogianis PA, Fazleabas AT and Verhage HG (1990) Localization of oviductal glycoproteins within the zona pellucida and perivitelline space of ovulated ova and early embryos in baboons (Papio anubis) Biology of Reproduction 43 340-346

Bradford MM (1976) A rapid and sensitive method for the quantitation of microgram quantities of protein utilizing the principle of protein-dye binding Analytical Biochemistry 72 248-254

Brown CR and Cheng WKT (1986) Changes in composition of the porcine zona pellucida during development of the oocyte to the 2- to 4-cell embryo Journal of Embryology and Experimental Morphology 92 183-191

Buhi WC, O'Brien B, Alvarez IM, Erdos G and Dubois D (1993) Immunogold localization of porcine oviductal secretory proteins within the zona pellucida, perivitelline space, and plasma membrane of oviductal and uterine oocytes and early embryos Biology of Reproduction 48 1274-1283

Dunbar BS, Prasad SV and Timmons TM (1991) Comparative structure and function of mammalian zonae pellucidae. In A Comparative Overview of Mammalian Fertilization pp 97-114 Eds BS Dunbar and MG O'Rand. Plenum Press, New York

Ellington JE (1991) The bovine oviduct and its role in reproduction: a review of the literature The Cornell Veterinarian 81 313-328

Eyestone WH and First NL (1989) Co-culture of early cattle embryos to the blastocyst stage with oviductal tissue or in conditioned medium Journal of Reproduction and Fertility $85715-720$

Fazleabas AT and Verhage HG (1986) The detection of oviduct specific proteins in the baboon (Papio anubis) Biology of Reproduction 35 455-462

Feigelson M and Kay E (1972) Protein patterns of rabbit oviducal fluid Biology of Reproduction 6 244-252 
Fox LL and Shivers CA (1975) Immunologic evidence for addition of oviductal components to the hamster zona pellucida Fertility and Sterility 26 599-608

Gandolf F and Moor RM (1987) Stimulation of early embryonic development in the sheep by co-culture with oviduct epithelial cells Journal of Reproduction and Fertility 81 23-28

Gandolfi F, Brevini TAL, Richardson L, Brown CR and Moor RM (1989) Characterization of proteins secreted by sheep oviduct epithelial cells and their function in embryonic development Development $106303-312$

Gerena RL and Killian G) (1990) Electrophoretic characterization of proteins in oviduct fluid of cows during the estrous cycle Journal of Experimental Zoology 256 113-120

Grippo AA, Way AL and Killian GJ (1995) Effect of bovine ampullary and isthmic oviductal fluid on motility, acrosome reaction and fertility of bull spermatozoa Journal of Reproduction and Fertility 105 57-64

Hill JL, Marshall JT and Nancarrow CD (1992) Effect of an oestrus-associated oviducal glycoprotein on early ovine embryo development Proceedings of the Australian Society of Reproductive Biology 24104

Kapur RP and Johnson LV (1985) An oviductal fluid glycoprotein associated with ovulated mouse ova and early embryos Developmental Biology 112 89-93

Kapur RP and Johnson LV (1986) Selective sequestration of an oviductal fluid glycoprotein in the perivitelline space of mouse oocytes and embryos Journal of Experimental Zoology 238 249-260

Kavanaugh JF, Grippo AA and Killian GJ (1992) Cannulation of the bovine ampullary and isthmic oviduct Journal of Investigative Surgery 5 11-17

Killian GJ, Chapman DA, Kavanaugh JF, Deaver DR and Wiggin HB (1989) Changes in phospholipids, cholesterol and protein content of oviduct fluid of cows during the oestrous cycle Journal of Reproduction and Fertility 86 419-426

King RS and Killian GJ (1994) Purification of bovine estrus-associated protein and localization of binding on sperm Biology of Reproduction 51 34-42

King RS, Anderson SH and Killian G) (1994) Effect of bovine oviductal estrus-associated protein on the ability of sperm to capacitate and fertilize oocytes Journal of Andrology 15 468-478

Laemmli UK (1970) Cleavage of structural proteins during the assembly of the head of bacteriophage $\mathrm{T}_{4}$ Nature (London) 227 680-685

Léveillé M-C, Roberts KD, Chevalier S, Chapdelaine A and Bleau G (1987) Uptake of an oviductal antigen by the hamster zona pellucida Biology of Reproduction 36 227-238
Lippes J and Wagh PV (1989) Human oviductal fluid (hOF) proteins. IV. Evidence for hOF proteins binding to human sperm Fertility and Sterility 51 89-94

Lippes J, Krasner J, Alfonso LA, Dacalas ED and Lucero R (1981) Human oviductal fluid proteins Fertility and Sterility 36 623-629

McNutt TL and Killian GJ (1991) Influence of bovine follicular and oviductal fluids on sperm capacitation in vitro. Journal of Andrology 12 244-252

McNutt T, Rogowski L, Vasilatos-Younken R and Killian GJ (1992) Adsorption of oviductal fluid proteins by the bovine sperm membrane during in vitro capacitation Molecular Reproduction and Development 33 313-323

McNutt TL, Olds-Clarke P, Way AL, Suarez SS and Killian GJ (1994) Effect of follicular or oviductal fluids on movement characteristics of bovine sperm during capacitation in vitro. Journal of Andrology 15 328-336

Minami N, Bavister BD and Iritani A (1988) Development of hamster two-cell embryos in the isclated mouse oviduct in organ culture system Gamete Research 19 235-240

Oliphant G and Ross PR (1982) Demonstration of production and isolation of three sulfated glycoproteins from the rabbit oviduct Biology of Reproduction $26537-544$

Pinkert CA, Kooyman DL, Baumgartner A and Keisler DH (1989) In vitro development of zygotes from superovulated prepubertal and mature gilts Journal of Reproduction and Fertility 87 63-66

Sakai Y, Araki Y, Yamashita T, Kurata S, Oikawa T, Hiroi M and Sendo F (1988) Inhibition of in vitro fertilization by a monoclonal antibody reacting with the zona pellucida of the oviductal egg but not with that of the ovarian egg of the golden hamster Journal of Reproductive Immunology 14 177-189

Sutton R, Nancarrow CD, Wallace ALC and Rigby NW (1984) Identification of an oestrus-associated glycoprotein in oviductal fluid of the sheep Journal of Reproduction and Fertility 72 415-422

Towbin H, Staehelin T and Gordon J (1979) Electrophoretic transfer of proteins from polyacrylamide gels to nitrocellulose sheets: procedure and some applications Proceedings of the National Academy of Sciences USA 76 43504354

Way AL, Schuler AM and Killian GJ (1997) Influence of bovine ampullary and isthmic oviductal fluid on sperm-egg binding and fertilization in vitro. Journal of Reproduction and Fertility 109 95-101

Wegner CC and Killian GJ (1991) In vitro and in vivo association of an oviduct estrus-associated protein with bovine zona pellucida Molecular Reproduction and Development 2 77-84 